Virginia Wink Hilton

Reich, Lowen and the IIBA: facing the challange of a conflict-ridden world 
Bibliographic information of Die Deutsche Nationalbibliothek (The German Library) The Deutsche Nationalbibliothek lists this publication in the Deutsche Nationalbibliografie; detailed bibliographic data are available at http://dnb.d-nb.de.

2006 Psychosozial-Verlag GmbH \& Co. KG, Gießen, Germany

info@psychosozial-verlag.de

www.psychosozial-verlag.de

\section{(c) $\underset{\mathrm{BY}}{\mathrm{N}} \Theta$}

This work is licensed under the Creative Commons Attribution-NonCommercialNoDerivatives 4.0 International License (CC BY-NC-ND 4.0). This license allows private use and unmodified distribution, but prohibits editing and commercial use (further information can be found at: https://creativecommons.org/licenses/by-nc-nd/4.0/). The terms of the Creative Commons licence only apply to the original material. The reuse of material from other sources (marked with a reference) such as charts, illustrations, photos and text extracts may require further permission for use from the respective copyrights holder.

Cover image: Ferdinand Hodler Ausschreitende Frau ,1910, oil on canvas, 48,5 x $39 \mathrm{~cm}$

https://doi.org/10.30820/0743-4804-2006-16

ISBN (PDF-E-Book) 978-3-8379-6879-8

ISBN (Print) 978-3-89806-517-7

ISSN (Online) 2747-8882 · ISSN (Print) 0743-4804 


\title{
Reich, Lowen and the IIBA: Facing the Challange of a Conflict-Ridden World ${ }^{1}$
}

\author{
Virginia Wink Hilton
}

\section{Summary}

This paper addresses the double emphases of the 2005 International Conference: the theme of »Human Nature and Conflict Resolution « and the 50th anniversary of the IIBA. The author summarizes the lives and the contributions of Wilhelm Reich and Alexander Lowen in light of the theme, and as prelude to the development of the International Institute for Bioenergetic Analysis. Particular attention is given to the major conflicts, both personal and socio-cultural, that arose in the lives of these men, and their differing responses to them. The question is addressed: What can we glean from our history that may give us inspiration, and a realistic sense of direction for contributing to healing and to change in these conflict-ridden times?

Key words: Wilhelm Reich, Alexander Lowen, History of IIBA, Sociocultural conflict, Sexuality, Sexual Politics

Regardless of differing political perspectives, we can all agree that the times we live in are dangerous, baffling, and deeply discouraging. Daily we are overwhelmed by vivid accounts of violence and conflict in almost every part of the world. Although they are less bloody, we experience appalling and wrenching conflict here in the United States between political perspectives and lifestyles. And I am certain that there are those of us here who are discouraged and disillusioned by the conflicts that exist within our own Institute. And of course on a daily basis in our therapy practices, our clients bring their myriad of internal conflicts and traumas to us, hoping for resolution and change. It's a struggle not to be exhausted with it all, not to want to keep it simple and turn off the news. Forget external conflicts; the internal is quite enough, thank you very much!

Reich was keenly aware of man's internal conflicts but also had a life-long

1 Address given at IIBA International Conference at Cape Cod. Massachusetts, May, 2005 Conference Theme: HUMAN NATURE AND CONFLICT RESOLUTION 
concern with the socio-cultural conflicts that both cause and reflect the internal ones. Lowen, while aware of the cultural conflicts of our day, chose to focus on the internal: healing the mind-body split in the individual. The Institute was formed to further this goal. But those who chose the theme for this conference hold the belief that we must address our internal conflicts, our organizational ones and those of the world we live in.

So we ask the question, what can we glean from the history of our founders' lives and the life of the Institute - the ideas, the successes, and the failures that may give us inspiration, and a realistic sense of direction for contributing to healing and to change on all these levels in these conflict-ridden times?

\section{Wilhelm Reich}

[For Reich's story I have relied heavily on the brilliant biography by Myron Sharaf, published in 1983.]

Wilhelm Reich was born on March 24, 1897, and grew up on a large and prosperous farm in a northern province of the Austro-Hungarian Empire. His father was stern and demanding in relation to his son, and fiercely jealous and abusive toward his wife. Reich's mother doted on Willy, and he in turn adored her.

Reich had a rather idyllic childhood on the farm that allowed him to observe and be stimulated by the natural phenomena of animals and plants, as well as human beings. Then, when he was around twelve years old, his mother began having an affair with his highly revered tutor who lived on the premises. Willy secretly spied on them, and eventually, apparently, revealed to his father what was taking place. As a result, the tutor was banished. Shortly after, his mother committed suicide. This tragic series of events no doubt had profound effects on Wilhelm, fueling some of his achievements on the one hand, and contributing to the complex and dark aspects of his personality on the other. Apparently, this crisis in his life at such a formative stage, was never dealt with fully in analysis.

Reich's father died of tuberculosis in 1914. After that, Reich managed the farm alone for a period until he was forced to flee when the Russian army invaded the countryside. He then went into the army in 1915 at age 18. In 1918, Reich went to Vienna for his professional education. There he quickly became immersed in the tremendous intellectual ferment of the time. He entered law school briefly, then switched to medicine. Soon he encountered Freud's young science, psychoanalysis. 
Reich was profoundly impacted by the person of Freud, and Freud was apparently also impressed with Reich, because he referred patients to him by early 1920 when Reich was only twenty-three. At the same time, Freud did not accept him as a patient, to the deep disappointment of Reich. He was engaged in only two brief periods of psychoanalysis, both with analysts who ended up later bitterly disliking him and his ideas.

When Reich joined the analytic circle there was no training curriculum and few guidelines for doing psychoanalysis. Reich organized and presided over a technical seminar for his peers where he urged them to present particularly their failures. Over the next few years he expanded and combined existing ideas into a systematic character-analytic approach. He uniquely emphasized the necessity of accessing the negative transference and eliciting strong emotional expressions beneath the character resistance. So at a very young age Reich was making acknowledged contributions within the analytic circle. At the same time he was arguing that the goal of psychoanalysis was to achieve orgastic potency. This was certainly a different emphasis from that of Freud and his other colleagues.

Following World War I, which left much devastation and poverty among the Austrian people, the country was highly polarized between the secularminded Social Democrats who wanted reform, and the Christian Socialist party, which was heavily Catholic in religion, conservative in economics, and rural in constituency. [The political situation in Austria at that time certainly bore some resemblance to the "red " and "blue" landscape of America today.] Reich was drawn to the Youth movement of the Social Democrats.

In 1927 a group of WWI veterans who were members of an extreme right wing group within the Christian Socialist party, fired shots into a group of Social Democrats, killing a man and a small child. The accused perpetrators were brought to trial but acquitted. This angered the workers in Vienna who organized a large protest strike and marched to the courthouse in front of which they started a fire. Reich and his first wife, Annie, joined the protest, and when the police started shooting into the crowd, they ducked behind a tree. After three hours, 89 people were killed and over a thousand wounded. This was the event that radicalized Reich.

Thereafter, Reich became actively engaged in the political issues and social struggle of the left, which at that time included the Communist party, but he was also asking deeper questions about »mass psychology «, why people are drawn to one political perspective or another. »He gradually came to realize that the main problem lay in the character structure of the masses themselves, especially their fear of freedom and responsibility« (Sharaf p.127). 
Meanwhile Reich began what he termed the »sex-pol« movement, which included the establishing of sex hygiene clinics. This effort was a kind of »community psychiatry «. His prolific speech-making metamorphosed from psychoanalytic theory to discussing the practical matters around sexuality. He went about the suburbs and rural areas, speaking to ordinary people about orgasm, contraception, a woman's right to choose abortion based on emotional and/or economic factors, and he inveighed against a sexual double standard for women. He emphasized affirming childhood sexuality rather than just tolerating it. He wanted to take a prophylactic approach to the neuroses: if children were allowed to express their sexuality rather than repressing it, they would grow up to be unarmored. He believed that it was the armoring that prevented a person from responding to social needs in a compassionate and humane way. And he believed that repressed sexuality was the source of many ills, including passivity in the face of authoritarianism, conflict of all sorts, and perverse and violent acts.

The political right responded by proclaiming the need for morality, law and order, and protection against those who would erode the values of the family. [Does this sound familiar?]

By 1930, Reich's analytic colleagues in Vienna, while positive toward his ideas regarding character defenses, were quite negative toward his emphasis on sexuality. And the Social Democratic party expelled him for being too critical of its leadership. So Reich moved to Berlin to join other young analysts (Otto Fenichel, Karen Horney, Eric Fromm), and where he expected his colleagues and the Communist party to be more open to his ideas as well as his social involvement.

In Berlin, which a few years later became the capital of fascism, Reich established the German Association for Proletarian Sex-Politics, which quickly grew to have 40,000 members. This group set about to establish sex clinics in several German cities. Get this: their goal was massive propaganda for birth control and free distribution of contraceptives; abolition of antiabortion laws; freedom of divorce, elimination of prostitution, elimination of venereal diseases; avoidance of neuroses and sexual problems by a lifeaffirming education; training for doctors, teachers, social workers in matters relevant to sexual hygiene; treatment rather than punishment for sexual offenses; and protection of children and adolescents against adult seduction. He also encouraged adolescent sexuality as a natural, healthy expression, and the acceptance of childhood sexuality on the part of parents. [Now, seventyfive years later, the U.S. government is doing its best to abolish sex education and replace it with abstinence training!] 
Reich, Lowen and the IIBA: Facing the Challange of a Conflict-Ridden World

Meanwhile, Reich was keenly aware (unlike most Germans at the time) of the growing impact of the propaganda of Adolf Hitler. He believed that the Germans were caught by their simultaneous desire for freedom and their fear of it. Hitler played on this conflict, and as one historian commented, it was Hitler's "art of contradiction which made him the greatest and most successful propagandist of his time « (p.165). Sharaf comments, »Hitler did not require people to think through the facts seriously; he would take care of everything for them « (p.166). [It's difficult not to feel some shocking parallels between the tactics of the propagandists of our day and those of the "most successful propagandist of his time".]

At the same time that Hitler was gaining power in Germany, the Communist party was turning against Reich for his position on adolescent sexuality. The Analytic Society and Freud himself were becoming antagonistic to him because of his commitments to the Communist Party, his disagreement with Freud on the death instinct, and his extreme ideas regarding sexuality. His contract for publication of Character Analysis was canceled, and Reich was eventually denied membership in the International Analytic Association.

Reich moved to Copenhagen in 1933, where he immediately came into conflict with the Communist Party over sexual material in articles he had written. The Party expelled him. And after only a few months an article appeared in a Danish newspaper calling for Reich's expulsion from the country, in order »to prevent one of these German so-called sexologists from fooling around with our young men and women and converting them to this perverse pseudo-science« (185).

Reich lived in Sweden briefly, where he was again harassed, then moved to Norway in 1934. Wherever he went, intelligent, talented people sought him out to become his patients or his students. A practice always quickly developed. He always approached his work with passion, complete dedication, an incessant curiosity and a mind forever capable of »thinking outside the box«. One area of inquiry always led to another.

In Norway, Reich turned his attention to science. His focus on the processes of energy release and changes in the body and energy in sexual excitation and orgasm led him to conduct what he called bio-electrical experiments, which in turn led to his discovery of »bions «. [I will not give more details about these experiments, except to say that Reich believed » he had succeeded in revealing experimentally the developmental living process that was continually occurring in nature (p. 222)]. Several well-known scientists in Norway became bitterly opposed to Reich and publicly denounced him as untrained and unqualified to do this scientific research. Opposition was joined by an 
eminent psychiatrist who denounced him for seeing patients in bras and shorts to observe their musculature, and other disgraceful practices. In a year's time, over a hundred articles denouncing Reich were published in leading Oslo newspapers!

In August of 1939 he left for the United States, just as World War II was about to break out.

Beginning in 1940, Reich taught a course for two semesters at The New School for Social Research entitled »Biological Aspects of Character Formation «. About eight or ten of Reich's students pursued their interest in his work by becoming a part of a weekly seminar that met in his home. Some became his patients. (Alexander Lowen was one of these.)

By the time Reich began his life in America, his interest in therapy was diminished. While his psychiatric practice provided his income and his contact with people, it was biology, physics and education which preoccupied him. During his first year he discovered what he called »orgone energy « what he believed to be a physical, biological energy in all living matter. Reich's experiments with orgone energy eventually led to the construction of the orgone accumulator, a wood and metal box that attracted and confined atmospheric orgone energy. When he later asserted that the energy accumulator belped in the treatment of cancer »he was dismissed by practically everyone as a sincere but psychotic >former psychoanalyst < or as a swindler" (p. 294). (This in spite of the fact that there were numerous accounts by cancer patients of improvement after the accumulator treatment).

The birth of Reich's son, Peter, in 1944 intensified his interest in the life of the infant. During the years that followed, he made some invaluable contributions to care and treatment of infants that were far from the common practices of the times. He emphasized the importance of the energy between mother and infant through eye contact and touch, he advocated picking up the baby when he cried, natural childbirth, little or no medication during and following delivery. He taught mothers what he called »emotional first aid «. He established the Orgonic Infant Research Center, which, like many of his projects, had a »short but vivid life«.

There was suspicion of and opposition to Reich and his work from the very beginning of his years in America, and this included a three-week incarceration by the FBI on Ellis Island in 1941 for no clear reason. Snide articles and rumors came from both the left and the right. All this accelerated after 1947 when an article appeared in The New Republic, entitled "The Strange Case of Wilhelm Reich«. The author, Mildred Edie Brady, according to Sharaf, skillfully combined truths, half-truths, and lies in writing about Reich. 
»Orgone, named after the sexual orgasm, is, according to Reich, a cosmic energy. It is, in fact the cosmic energy. Reich not only discovered it; he has seen it, demonstrated it and named a town - Orgonon, Maine - after it. Here he builds accumulators of it which are rented out to patients, who presumably derive >orgastic potency< from it « (p. 360).

She insinuated that Reich was a megalomaniac and a swindler, that the psychoanalytic association should »do something about the Reich cult « or »the government will«. Many writers thereafter relied on Brady as the major source of their information regarding Reich, and these judgments permeated their articles and became the prevailing attitude toward him. But most significantly, Brady's article alerted the Food and Drug Administration who then began an investigation of Reich and the accumulators.

In 1950, while the battle with the FDA was going on, Reich moved permanently to Maine. There he was intensely occupied with writing, such as »Listen Little Man«, and »Murder of Christ«, along with his scientific investigations that took him into some »far out « places. He conducted the Oranur experiments, exposing radium to orgone energy, with hopes that the latter would ameliorate the effects of radiation. These experiments were in response to his deep concern about the atomic bomb and the effects of nuclear energy. He organized »cloud busting « techniques whereby he attempted (and managed) to produce rain in drought stricken areas. These experiments raised Reich's ecological consciousness. Observing what he believed to be the impact of what he called DOR (deadly orgone energy) on the environment, he became concerned not just with radiation and nuclear effects, but also with chemical pollution and non-nuclear forms of electromagnetic emissions. Here again, while at the time seeming paranoid, Reich anticipated many concerns that became widely held in subsequent years.

Reich came to believe that mental illness, physical illness and »social« problems (like war, violence, and crime) were all aspects of what he referred to as the Emotional Plague. Blocked energy and the resulting armor and rigidity prevent persons from growing and flowing naturally. He believed that central to this armoring is sexual repression. The repressed person and repressed societies will have a layer of intolerance and persecutory behaviors that will erupt violently from time to time. He also observed that attempts to abruptly unarmor the individual or call attention to it in society, results in extreme reactive behavior. This he surely learned from his own experience.

Using the kind of tactics that Reich attributed to the "emotional plague", Senator Joseph McCarthy helped create the atmosphere of fear and suspi- 
cion that made the attack on Reich possible in America. The FDA began investigating the accumulators around 1951. According to Sharaf, the government's tests on the accumulator were flawed and inadequate, hardly meeting the requirements for scientific investigations. Yet, in February, 1954, the state of Maine, at the FDA's request, filed a complaint for an injunction against Reich and against the interstate shipment of accumulators. The complaint maintained that their investigators had proved the nonexistence of orgone energy. It implied that Reich was a profiteer on human misery and the accumulator was worthless. All of Reich's writings published in America were considered propaganda.

Reich refused to defend himself on grounds that the government had no right to interfere with scientific investigations. When he did not appear in court, an injunction was issued ordering the recalling and destroying of accumulators and the destruction of his publications.

After several days of what we might now call »shocked immobility «, Reich expressed his rage by declaring that he would produce a storm to prove the existence of orgone energy. And sure enough, following his cloud-busting operations, snow and rain appeared, which had not been forecast!

Reich fought hard against the injunction that he believed to be unconstitutional. But to no avail. He was arrested in Washington, D.C. on May 1, 1956 and brought to trial two days later. The charge was violation of the injunction against the accumulator. He was sentenced to two years in federal prison. The court of appeals affirmed the decision of the district court, and the Supreme Court refused to review Reich's case.

In June of 1956, FDA agents arrived at Orgonon to supervise the destruction of the accumulators. Reich's colleagues, joined by his twelve year old son, Peter, chopped up the accumulators with axes. Two months later, six tons of literature were burned in New York City in the garbage dump on the 125th St. Pier! The ACLU sent out a press release criticizing the burning of Reich's books. The release was never published by any major newspaper in the U.S.

Reich went to federal prison on March 11, 1957. The psychiatric evaluation was: "paranoia manifested by delusions of grandiosity and persecution and ideas of reference« (p. 469). Reich had been very lonely during the last years of his life, burdened by the stress of the investigations, drained by his intensified and almost fevered efforts to write, to experiment, to engage in various ways against the »emotional plague«. During those days, while quiet, deep, and profound in his observations, he also could be delusional and paranoid, and often had angry outbursts. Friends and colleagues left him in frustration and disillusionment, and so did the women in his life. 
Reich, Lowen and the IIBA: Facing the Challange of a Conflict-Ridden World

During Reich's prison stay, the chaplain commented on his deep loneliness. Reich told his son that he cried a lot, and encouraged Peter to do likewise. One week before a possible parole, Reich died in his sleep, officially of a heart attack. Sharaf wrote that he died of heartbreak (p. 477).

Wilhelm Reich, while rarely fully credited, made an enormous difference with everything he undertook. While orgonomy in its classic form never expanded much, his ideas and practices had a huge impact on psychoanalysis and, even more, psychotherapy. In addition to the theory of character structure, relating face to face with patients, connection of mind to body, use of touch - these ideas are a part of his on-going contribution.

The social movements that occurred ten to twenty years after Reich's death - the human potential movement, the women's movement, and the socalled sexual revolution - were all heavily influenced by his writing. His observations and work around child-birth and childrearing have become acceptable practice following the infant studies of the last two decades.

»When one reads of Reich's achievements in summary form, much of what he says seems so simple and obvious. It is easy to over look the fact that no one in his time was seeing and doing what he was seeing and doing" (p., 333).

As Sharaf put it, Reich was "passionately engaged in the social and scientific conflicts of his time $(. .$.$) . And in the struggle he »saw with blinding clarity$ that he had disturbed the sleep of the world ...« (p. 10).

The great visionaries pay a huge price-often with their life-for being ahead of their time. But change has happened, and the world is never again the same.

\section{Alexander Lowen: The Father of Bioenergetic Analysis}

[I am telling Al's story mostly from his own point of view, as expressed in his autobiography, Honoring the Body, published in 2004.]

Alexander Lowen was born on December 10, 1910 in New York City to Russian Jewish immigrant parents. He states that his mind-body split came from the differences between them; his father was a pleasure-oriented, nonachieving, gentle man, while his mother was rigid, demanding, controlling and unsatisfied. (Thus, in terms of personality, his parents were the opposite of Reich's.) His childhood was spent playing in the streets of Harlem, and his 
adolescence playing handball. This physical life, he said, substituted for the absence of a warm emotional life at home.

As a child he was severely shamed around sexuality. At age 13 he discovered masturbation, which he indulged in almost daily, feeling that this behavior represented a great weakness in his personality. He was very lonely all during high school and college, spending time after school helping his father with his laundry business when not doing homework. He had few friends, no girl friends, and was never invited to parties. He writes that sports and masturbation saved him in his youth.

Lowen took the required education courses at the New School for Social Research, and in 1933 he became a high school teacher. He studied law at the same time and got his L.L.B. degree in 1934 summa cum laude. Even the highest honors could not, during those difficult depression years, land him a job in a law firm that paid more than his teaching position. So he continued studying for a doctorate in law, hoping to become a law professor. However, he only graduated magna cum laude, which apparently didn't qualify him for a professorship.

In 1938 he experienced a depression which he recognized was a result of an absence of excitement in his body, and which he believed to be due to the lack of physical activity. He began doing exercises daily, which had the desired result, and »made me realize that this is where I wanted to be - in my body, not my mind « (Lowen, p. 30). Working with the body, he said, saved his sanity. He wanted to understand more about the mind-body split.

In 1940 he was attracted to a course offered in the New School catalogue on Character Analysis, which proposed a fundamental unity between mind and body. That course, of course, was taught by Wilhelm Reich. Lowen's intense interest in Reich's subject led him to become a part of a weekly discussion group with Reich, and finally to become his patient. Interestingly, Lowen states that »the power of Reich's therapy was in the strength of his personality and the strength of his being " (p. 42). He drew energy from his therapist to face the sexual repression and shame that he carried, and in two and a half years of therapy was able to feel and surrender to his body in a way he did not know was possible.

Upon later reflection, Lowen felt his analysis did not go deep enough, and that his narcissism and desire for fame went unchallenged. Yet his work had given him a stronger sense of self and allowed him to grow to be more of a man. »Reich«, he says, »had changed my life« (p.42).

Reich emphasized breathing in the therapy, and by this time, was doing very little character analytical work. He taught that the therapist had to un- 
Reich, Lowen and the IIBA: Facing the Challange of a Conflict-Ridden World

derstand the energetic process in order for change to take place in the patient. Neither talking nor understanding could change the energetic dynamics. Change had to be created through the body, not the mind.

Following Reich's personal life would have added pages to this paper. But how different it is in the case of Lowen! In $1941 \mathrm{Al}$ met Rowfreta Leslie Walker, a student in the high school where he taught. After her graduation in 1942 they began a relationship. They were married in 1943. This relationship lasted until Leslie's death in 2002.

In $1947 \mathrm{Al}$ and Leslie sailed for Europe where $\mathrm{Al}$ attended medical school in Geneva, Switzerland. Al's recounting of those years indicates his awakening enthusiasm for European culture, as well as his love of pleasure.

When the Lowens returned in August, 1951, Leslie was eight months pregnant. Their son, Fred, was born on Sept. $27^{\text {th }}$.

After his internship, Al applied to the New York Board of Medical Examiners for permission to take the licensing exams. He was told that his application was held up pending an investigation into his moral fitness. He was to be called before the Board for a hearing. As he suspected, their concerns were related to his connection with Wilhelm Reich. »I told them how I met Reich, why I believed in his ideas, and why I believed Reich had much to offer medicine. I stated that I had practiced Reichian therapy for two years before I went to Geneva and that I would continue to practice this form of therapy focusing on psychosomatic medicine. They asked me if freeing a sretracted pelvis< wouldn't lead to sexual acting out, and I answered that it should have a contrary effect « (p. 76).

After the meeting Lowen was told that while he had impressed the Board, he should be careful, because there was a file on him. At that time Reich was under full investigation by the FDA, and Lowen felt that continuing to associate with the Reichians would put him in double jeopardy. So he said, »I knew I had to go my own way. This was not a difficult decision, because I was already skeptical of their therapeutic position « (p.77).

In 1953, Lowen met John Pierrakos, M.D, a Greek immigrant ten years his junior, who also was committed to Reich's ideas and work. They shared an office and worked with each other therapeutically, developing techniques that we use today. The two men were very different, and for a long time their differences complimented and enriched their work. Al describes the two of them as follows: John was solid and strong and more naturally physical and grounded, Al was slender and wiry and has always sought to be grounded. $\mathrm{Al}$ was the intellectual leader and the communicator. John was quieter and more often in the background. John, who was near-sighted but had strong 
peripheral vision, could see auras and orgone energy fields clearly. Al commented that he saw his patients clearly, whereas John felt them with clarity (p. 82).

$\mathrm{Al}$ and John were close friends and colleagues for almost twenty years. But in 1972 John met Eva, a mystic and a medium, who became his wife. The differences in beliefs and perspectives of the two men intensified, and the problems inherent in their relationship became more apparent. Al finally could not accept John's mysticism, nor what he felt were delusions emanating from the mysticism. John apparently had difficulty tolerating Al's dominance. The two went their separate ways in 1973.

In 1956 the Institute for Bioenergetic Analysis was established. This grew out of a seminar that had occurred regularly for the previous several years to discuss cases and ideas. Alice Ladas, who had been a member of the seminar, both encouraged this move and donated the funds for the attorney.

Al's first book, Language of the Body, was published in 1957. Although the book had a negative review in a psychoanalytic journal, it opened up interest in Bioenergetics. Lowen was invited to the National Institute for Mental Health to do a presentation. Dr. William Walling, a member of the Institute, and Dr. Pierrakos accompanied him. They were asked to do a demonstration wherein each of the three were called out one after the other to diagnose the same person based solely on viewing the body. Their diagnoses agreed. When Lowen explained the basis for the diagnosis, the response was that he needed to launch a research project to prove the validity of his thesis. Lowen states that he had no interest in doing a scientific study. This has remained true throughout his life. [One wonders if Reich's experiences around his scientific work influenced Al's position.]

Love and Orgasm was published in 1965, and Betrayal of the Body in 1967. It was the latter, Lowen states, that gave Bioenergetics the credibility it needed. He wrote eight other books after that. Al stated in his autobiography that his books were not as widely read as he had hoped. Yet for many years one could find more than one book by Alexander Lowen in the psychology section of the book stores at any given time. They brought many people in touch with his ideas and with Bioenergetic therapy. Lowen was invited to Esalen Institute in 1967, and he presented workshops there for a number of years following. It was also through his work there, and his workshops around the country and in Europe that many more people became involved in the training - and ultimately teaching - of Bioenergetic Analysis.

The first Bioenergetic conference was held in Isla Mujeres, off the coast of Mexico near Cancun, in 1971. There were about thirty or so participants. 
Reich, Lowen and the IIBA: Facing the Challange of a Conflict-Ridden World

The second conference was in Aspen, Colorado, with many more people present. Then, in 1976 an international congress was held in Waterville Valley, New Hampshire, »to transform the Institute for Bioenergetic Analysis into an international organization «. Following this meeting conference sites were alternated between North America and Europe: Mexico, Taormina, Italy, Catskills, Belgium, Montebello, Canada, Greece, Portugal, Poconos, Arles, Montebello, Italy, and finally in 2003, Brazil. During each of the conferences that $\mathrm{Al}$ attended up through 1996, his great love of pleasure - particularly dancing - was an essential and infectious ingredient. [Surely no group that contains so many people from the northern hemisphere dances quite like we do!]

Following the 1976 Waterville Valley conference, by-laws were written, a Board was elected, and trainers were appointed. Al was given the title of Executive Director. John Bellis, M.D., of New Haven Connecticut, was named Associate Director.

In 1977 after the by-laws were adopted, John Bellis' first action as the new associate director was »to send a long letter to all the members asking them to write him about their ideas and views of how the new Institute could serve them « (p. 91). Al reports in his autobiography that he was upset and infuriated by the letter.

He says: »I saw the focus of the Institute shifting from the development and growth of our understanding of Bioenergetic Analysis, both in its theory and practice, to building a larger organization that would serve the interest and needs of its members. Their interest was largely their personal gain through increased prestige, power and financial rewards as teachers and supervisors« (p. 91).

So in response to John Bellis' letter, Lowen announced that he was resigning from the Institute. After a brief, intense, and somewhat panicky period, the newly appointed trainers urged $\mathrm{Al}$ to stay on. He did so, with a Board which he appointed, and with Ed Svasta designated as the person who would handle relations with the international trainers and their societies. John Bellis resigned as Director, but remained a part of the training faculty for a number of years.

For the next twenty years $\mathrm{Al}$ continued to lead the Institute, traveling frequently to parts of the U.S., to Europe and regularly to Greece, to do workshops, to teach his current techniques and consistent themes. But, as he states in his autobiography, he continued to experience deep disappointment in the level of the training programs, and the lack of full adherence to the principles that were central to his theory and practice. 
Al resigned as Executive Director of IIBA at the 1996 conference in the Poconos. He comments that this allowed him to feel like a free person; he no longer felt responsible for the Institute or for what people did in the name of Bioenergetics. He concludes: »I am no longer in conflict about the International Institute for Bioenergetic Analysis « (211).

Lowen has stated that it takes a life-time to work through one's issues. »This is not to say «, he wrote, »that the person entering Bioenergetic therapy must commit himself to a therapist for life. He commits himself to life and that is the therapy. But it is a commitment to the body, to its life and to its feelings that is the curative process «. This is the core of Lowen's belief about his work. It is also the way he has lived his life.

Alexander Lowen, through his therapy, his teaching, his writing, and through the Institute which he founded, has touched and changed the lives of thousands of people. [He certainly changed and impacted mine in innumerable ways!] He established the Institute which has 55 societies in 17 countries. And as Charles Kelly said at the first USABP conference in his tribute to Al, every body psychotherapy approach, if not a direct descendant of Bioenergetics, owes a huge debt to Al Lowen. Those of us who are members of the Institute will say that at the very least we are indebted to him and to the Institute for our professional careers as Bioenergetic Analysts. And I know that there are many people in the world today who would say: »Bioenergetic Analysis has saved my life!«

\section{Institute}

From the Institute's beginning until now, there have been a number of dedicated people who have given so much: their talents, their energy, their time, and-some have felt - their life blood! While acknowledgment of these individuals is beyond the scope of this paper, I want to express my profound and enduring gratitude for what they have contributed not just to the Institute, but to the lives of each of us.

After Al Lowen resigned as Executive Director in 1996, the presidency (as it is now called) was assumed by Ed Svasta, myself, followed by Bill White, and currently Hugo Steinmann. As the shift occurred, there were those of us who believed that without Al, the Institute would have to change in order to survive and thrive. Our vision for the IIBA was: that the professional needs of its members would be addressed, and that the Institute would find its 
Reich, Lowen and the IIBA: Facing the Challange of a Conflict-Ridden World

rightful, valued place in the field of psychotherapy. Personally, my first concern was to meet with the Societies in Europe, the U.S., and in South America to hear first-hand their needs and concerns as Bioenergetic Analysts. I was surprised to discover when reading Al's autobiography the similarities between my intentions and those of John Bellis in 1976.

Those meetings were met with much enthusiasm and at that time created a lot of energy and responsiveness. People wanted to be heard, wanted to be involved. Part of the naivety that I brought to the position of Executive Director was to assume that the sense of community which was emerging would result in a cooperative, cohesive and expanding vision of what the Institute could become in the world. We learned rather quickly that when people have not had a voice, and suddenly there is the option to share authority, a great deal of conflict arises, a great deal of suppressed negativity erupts and latent power issues emerge. [I've sometimes thought the process of change and the chaos it creates may not be that different when an organization is changing from the single-person head to a participatory organization, than when a country is changing from a dictatorship to a democracy.]

New by-laws were put into place that gave all members a vote, and turned the Board of Trustees from a rubber stamp into a full decision making-body, responsible for the policies and actions of the Institute. Rubber stamps are quite efficient; democracies are not. We soon learned how costly, in time and in money. The administrative task envisioned seemed much too time demanding for a part-time faculty member to fulfill. Naïve area \# 2: An administrator was hired, presumably highly qualified, who stated: »If I can't raise my own salary, then I'm not the man for the job, « He didn't and he wasn't. This did not become fully apparent until the resources were drained, leaving much disarray and despair. [For my part in this portion of our history I feel deep regret. And to each person in the Institute I offer my profound apology.]

Meanwhile, a number of dedicated members have made extraordinary investments of hours and energy in implementing the changes that the members wanted. The leadership, no longer confined to international faculty members, has also shifted largely to Europe. This more accurately reflects the current distribution of the membership.

We are a smaller organization now. We have lost some members who liked it the old way, and members who feel that we don't have anything to offer them. Some conflicts and old injuries have been addressed, while others have not.

We have not become more widely recognized by the field of psychotherapy (in spite of the fact that scientific research from several directions points 
toward the importance - if not the necessity - of including the body in psychotherapy and emotional healing). Recently a psychologist and former client of mine asked the question: Why hasn't Bioenergetics become more a part of the mainstream? My first thought was, because we have not done enough research over the years. Then, recalling Reich's life, and the recent movie »Kinsey", and what happened to Alfred Kinsey in the 50s, I thought to paraphrase a well known quote - »It's sexuality, stupid! «. In this period when there has been the backlash to the excesses of the sexual revolution, and the horrors of the AIDS epidemic, as a therapeutic modality we are still identified with Reich's focus and Lowen's early emphasis upon sexuality. This along with the image of shouting and screaming and beating on pillows amounts to a stereotype that hardly does us justice.

So where are we now - as members of a shaky Institute and citizens of a violent and crazy world? What does our history tell us about who we are, and about how we can address conflict?

Reich seems to have created conflict wherever he went. Yet all his efforts were aimed at revealing or exposing conflict, and ameliorating it. For what is character structure but the way the individual found to resolve his conflict between his needs and the expectations of his environment? Yet this put him in conflict with his own true self, and left him bound and constricted by muscular armor. Reich worked with his patients through breathing and expression of deep emotion to release the armoring and to restore the natural flow of life energy. Yet he knew that the unarmored person would be caught in the same »trap " that is created by the armored masses of society - those who are stricken with the »emotional plague«. So one thing we learn from Reich's life is that it is dangerous to mess around with the way things are: whether in persons, institutions, or societies. He said, in » The Murder of Christ «, that every adult who has preserved his aliveness and who has the capacity to challenge others' immobility runs the risk of being killed by the forces that cannot tolerate aliveness (Sharaf, p. 397).

Yet from the time of the deadly demonstration in Vienna in 1927 until his death, he never stopped trying in a myriad of ways to improve life on this planet. In the end, he was disillusioned with therapy and politics. He felt that, because of the nature of character structure, it was through education alone that change would come about - after many years and many generations. Finally, he said, the hope of the world was in the unarmored infant.

In his autobiography Al Lowen says the following: »Reich believed (...) that he had a mission to save people by providing them with a deeper understanding of life and the natural forces that control it (...). Although I had 
Reich, Lowen and the IIBA: Facing the Challange of a Conflict-Ridden World

many similar feelings, I was not a revolutionary like Reich, as much as I wanted to see many changes in this culture. My founding of the Institute for Bioenergetic Analysis was motivated by a sincere hope that I would help alleviate the suffering of people« (Lowen, p. 94). In so doing, Lowen »brought to earth « the Reichian ideas, stressed the importance of grounding, created exercises and techniques which enliven the body and open the emotions to profound depths. The Institute grew and developed in its theory and teaching to provide a level of understanding and experience of the body/mind that I believe is not equaled in any other therapeutic modality. In that process we also developed a quality of connection and community, which because of the profound experiences we shared through our training and learning with each other, is rarely found anywhere.

Reich grew cynical about therapy and politics, but till the end of his life was attempting to make the world better. Lowen was pessimistic about society and politics, but he practices therapy to this day. Today we are discouraged about the struggles of the Institute, but we continue to bring in new students and great new trainers. While we may reject Reich's more grandiose desires to save the world, I believe that the times we live in - both in our field and in the world at large - simply demand that we as individuals and as an Institute engage on each of these levels: therapy, the organization, the world!

In regard to the Institute we may ask the question: Is what we have worth the struggle with budgets and bureaucracies, with personal disagreements and cultural differences just to keep the mission of IIBA alive? Do we continue the legacy of Reich and Lowen in this manner? Or is it time to let go and individually meld into the mainstream? Is our passion spent, or do we have some energy left for continuing and finding new ways to offer our unique contribution to the field of psychotherapy? Can we unleash the energy that is tied up in our internal conflicts - and direct what we have learned outward toward issues and projects that are begging for attention?

If so, then I think we need to apply a sense of urgency toward bealing the interpersonal and organizational wounds and conflicts that exist among us. We will be talking and listening together this week about specific ways to resolve conflict. In the conference brochure it is suggested that we approach our differences with an open mind and an open heart, that we learn shared ways of being with each other, of »moving to « and »reaching out«. What if, when we disagree in meetings or conversations, we were to simply put into instant practice that exercise Al taught us: of literally, silently reaching out to each other! I wonder what kind of barriers would fall! Then perhaps we would be in the position to look for the unexpressed needs beneath the obvious issues. 
Then, how can we, as members of the Institute, citizens of the world, and as plain old human beings concerned about the survival of the planet and the species, avoid the terrible urgency of addressing the global conflicts that confront us? Probably most of us still say, Look, I do my part on a one-to-one basis. The big picture is gloomy and overwhelming. And what good can I actually do anyway? Many of us here, I suspect, have had a war we didn't want, a president we didn't vote for. But, whatever our political persuasion may be, whatever country we reside in, surely we all feel helpless about many things, such as the chaos in the Middle East and the genocide in Darfur. How can we stop the world from destroying itself? How can we stop the earth - any more than ourselves - from dying?

In 1986 I was in North Germany doing a workshop a week or so after the fateful explosion of the nuclear plant in Chernobyl. The nuclear cloud had drifted, leaving its fall-out across Northern Europe. In that part of Germany background radiation levels were said to have been 3000 times above normal. People were in despair, and had great anxiety and concern, particularly for their children, because the short and long-term effects of the fall-out were unknown. We didn't drink milk or eat fresh vegetables. My American colleagues and I were struggling daily about whether to return to the states, or to continue with our European itinerary: in my case, whether to go on to Norway and then to Belgium for the IIBA conference. The Europeans whose environment was contaminated had no choice: I did. I went for a short walk in the forest with one of the participants as I verbalized my struggle. His response to me was life-changing. He said, »Martin Luther once said, >If I knew the world would end tomorrow, I would plant a tree today«. I decided at that moment that I would remain in Europe, partly as an act of solidarity with my European colleagues, and as a way of planting my own tree.

By the way, a similar quote is attributed to Martin Luther King, Jr., and several others. There are many tree-planters. But surely the most incredible tree-planter is Wangaari Maathai of Kenya, who was awarded the Nobel Peace Prize in 2004. [Her story has some parallels with the life of Wilhelm Reich.] Thirty years ago Kenya was in danger of becoming a desert, having lost $90 \%$ of its forests. Wangaari wanted to do something about that, so she planted a tree. She gathered together the impoverished rural women in her country, women who struggled daily to find firewood for their homes. They began to plant trees - real ones! They established the Greenbelt Movement, and in the process the women developed dignity, self-respect, and a sense of purpose. Wangaari was jailed and beaten many times for her »subversion«. 
Reich, Lowen and the IIBA: Facing the Challange of a Conflict-Ridden World

But in the years since, 30 million trees have been planted in Africa by Wangaari and the women of the Greenbelt Movement! How is that for making a difference!

But what can you and I do? In your office, when you help a person feel the ground and further connect to the ground of his/her own being - you've planted a tree. When you've helped your client open her sexuality and she's more alive in her body and in her relationships, you've planted a tree. When through your resonance you have provided a connection with your client that makes it possible for him to form an attachment with his children, you've planted trees. When you teach trainees how to help their clients resolve their inner conflicts through Bioenergetic practice, or when you write a research paper to further validate our theory in the field - you've planted trees. When you interact on behalf of Bioenergetics with other organizations and institutions, and give and gain new knowledge for helping people, you're planting trees! When we sign a petition or join a protest march on behalf of the values we stand for and work for, we're planting trees. When we open our minds and hearts and reach out across our differences to understand each other - whether in the Institute or in the Middle East - we're planting trees. If we can get our heads and our hearts together as an Institute and find innovative ways to alleviate the suffering of heretofore neglected groups of people - we're planting trees!

Reich ended his life with a broken heart, but he lived his passion with a fury to the end. Al Lowen believes he failed in what he set out to do, yet at 94 he still sees patients - he's still planting trees! Much of our vision for the Institute has not been realized. We may not achieve our goals. The world may end. We certainly shall. But until that time, let's combine vision with groundedness, approach conflict with open-heartedness, hold in our awareness the interconnectedness of every aspect of life, and finally, embrace the world and each other with gratitude for the aliveness and passion and love we've been given, and give it back - whenever and wherever possible!

\section{References}

Lowen, A (1958) The Language of the Body, Macmillan, New York.

Lowen, A (1965) Love and Orgasm, Macmillan, New York.

Lowen, A (1967) The Betrayal of the Body, Macmillan, New York.

Lowen A (2004) Honoring the Body, Bioenergetic Press, Alachua, Florida.

Reich W (1974) Listen Little Man. Farrar, Straus, and Giroux, New York, New York.

Reich W (1970) The Mass psychology of Fascism. Farrar, Straus, and Giroux, New York. 
Reich W (1953) The Murder of Christ. Farrar, Straus, and Giroux, New York.

Sharaf M (1983) Fury on Earth, St. Martin’s Press, New York.

Wilson C (1981) The Quest for Wilhelm Reich. Anchor/Doubleday, Garden City, New York.

Wilson R A (1987) Wilhelm Reich in Hell, foreword by Hyatt C S \& Homes D, Falcon Press, Phoenix, Arizona.

\section{About the Author}

Virginia Wink Hilton, LCSW, PhD, began practice as a Bioenergetic therapist in 1975 in New York City. She moved to Southern California in 1985, and since that time has continued a private practice with her husband, Robert Hilton. She has been director of training for the Southern California Institute for Bioenergetic Analysis, chair of the IIBA ethics committee, and served as Executive Director for the International Institute for Bioenergetic Analysis. She has been privileged to teach in many societies for the IIBA. Her particular interests have been in sexual issues in the therapeutic process, professional ethics and the relationships between sociocultural issues and personal process. Her publications include: »Working with Sexuality«, »On Becoming More Fully Alive: The Masculine and Feminine Principles«, »When We Are Accused « (Journal for the International Institute for Bioenergetic Analysis); and »The Devil in America "(The California Therapist). She is a co-author of »Therapists at Risk «.

Virginia Wink Hilton, Ph.D.

150 Paularino Ave. Suite 185

Costa Mesa, CA 92626

vbilton@cox.net 